\begin{tabular}{|l|l|}
\hline & \\
&
\end{tabular}

SEÇÃO ARTIGOS E ENSAIOS

\title{
A atualidade da estratégia baseada na dualidade de poder
}

The timeliness of the strategy based on power duality

\section{Fernando Frota \\ Dillenburg ${ }^{1}$}

orcid.org/0000.0002.3006.8490

ffrotadillenburg@gmail.com

Recebido em: 4 set. 2020. Aprovado em: 4 jan. 2021. Publicado em: 01 jul. 2021.

\section{(c) (1)}

Artigo está licenciado sob forma de uma licença Creative Commons Atribuição 4.0 Internacional.
Resumo: O objetivo desse artigo é tratar do significado do fenômeno do "duplo poder", algo presente desde as revoluções burguesas até as revoluções proletárias. Os sovietes (conselhos) de trabalhadores das Revoluções Russas de 1905 e 1917 ganham destaque no texto como exemplos da dualidade de poder. A questão que surge é se toda a revolução proletária deve necessariamente passar por um momento de duplo poder, ou, ao contrário, o choque entre dois Estados é algo que se tornou anacrônico. O texto contém observações de autores que participaram ativamente de revoluções, como Marx, Engels, Lênin, Trotsky, Zinoviev, Rosa Luxemburgo e Gramsci, além de diversos comentadores. Com este texto pretende-se contribuir com o debate sobre a estratégia a ser assumida pelo proletariado mundial.

Palavras-chave: Duplo poder. Marxismo. Revolução Russa.

Abstract: This article approaches the meaning of the phenomenon of double power which is observed since the bourgeois revolutions until the proletarian revolutions. The workers' soviets (councils) of the Russians Revolutions of 1905 and 1917 are highlighted as examples of the duality of power. The relevant issue here is whether the whole proletarian revolution must necessarily undergo a moment of double power or, otherwise, the clash between two States is something that has become anachronistic. The text contains observations from authors who actively took part of revolutions, such as Marx, Engels, Lenin, Trotsky, Zinoniev, Rosa Luxemburgo and Gramsci in addition to several commentators. This article intends to contribute to the debate on the strategy to be assumed by the worldwide proletariat.

Keywords: Double Power. Marxism. Russian Revolution.

\section{Introdução}

"Ao lado dos governos oficiais, os operários deverão formar governos revolucionários, compostos por clubes e comitês operários [...] Seu grito de guerra deve ser: a Revolução Permanente".

(Karl Marx e Friedrich Engels)

Este trecho citado em epígrafe foi escrito por Marx e Engels em 1850 após a derrota do proletariado na Revolução de 1848 é uma sintese do que ficou conhecido como o processo de dualidade do poder. $\mathrm{O}$ duplo poder é considerado pelos autores como parte indispensável da estratégia geral da revolução permanente, isto é, um caminho que o proletariado mundial precisa necessariamente percorrer até que as 
forças produtivas decisivas do planeta estejam em suas mãos (MARX; ENGELS, [195-], p. 86).

Mas o que significa o duplo poder? Conforme indica o trecho acima citado, no capitalismo a dualidade de poder é um processo de constituição de governos operários ao lado dos governos burgueses. Segundo Zinoviev (2013, p. 87) os organismos de duplo poder, que nas revoluções russas foram representados pelos sovietes (conselhos), "significa a ditadura do proletariado [enquanto] a assembleia nacional significa a ditadura da burguesia". E conclui Zinoviev, à luz da teoria de Marx e Engels: "é impossivel unir e conciliar a ditadura dos operários com a ditadura da burguesia" (ZINOVIEV, 2013, p. 87). A situação de dualidade de poder, instável por natureza, não pode permanecer por muito tempo. Essa situação terá que ser, necessariamente, decidida pela vitória de uma das duas classes em luta. Nesse sentido afirmou Trotsky no Programa de Transição, em 1938: Na dualidade de poder, "dois regimes [...] opõem-se irreconciliavelmente um ao outro. O choque entre eles é inevitável" (TROTSKY, 2009, p. 62). Mas, de acordo com Trotsky, a construção do duplo poder não determina qual das duas classes será a vitoriosa: "Do resultado desse choque depende a sorte da sociedade. No caso de derrota da revolução, a ditadura fascista da burguesia. No caso de vitória, o poder dos conselhos, isto é, a ditadura do proletariado e a reconstrução socialista da sociedade" (TROTSKY, 2009, p. 62). Os períodos de dualidade de poder correspondem, portanto, a um ponto culminante da luta de classes, um período que tende a ser de curta duração (ANWEILER, 1975, p. 148).

Uma das formas clássicas de duplo poder ocorreu na Revolução Russa. Analisemos a criação do duplo poder nos diferentes momentos da revolução proletária naquele país.

\section{Os sovietes na Revolução Russa de 1905}

A explosão das massas trabalhadoras que deu origem à Revolução de 1905 na Rússia foi o resultado de um longo processo de gestação. Nos últimos anos do século XIX, o Estado injetou recursos na indústria e na infraestrutura. Surgiam grandes indústrias ao redor de São Petersburgo, de Moscou e na região de Donbas, na Ucrânia. Foi criado um amplo programa de construção de ferrovias por toda a Rússia. Enfrentando péssimas condições de trabalho, a classe operária se organizava (MIÉVILLE, 2017, p. 24). No interior desse processo de acirramento das contradições de classes, no início de 1905 quatro líderes operários são demitidos pela direção da fábrica Putilov, uma das mais importantes indústrias metalúrgicas de São Petersburgo, que explorava mais de 12 mil trabalhadores. Como reação às demissões, os operários entraram em greve no dia 3 de janeiro. Em menos de uma semana ela tinha se transformado numa greve geral em toda a cidade.

Nessa época, o governo estava bastante fragilizado devido à fragorosa derrota na guerra contra o Japão. Segundo Achcar (2009, p. 71-72), até mesmo a oposição liberal, que havia apoiado o início da guerra, depois das sucessivas batalhas derrotadas, passou a criticar o governo. A capitulação das forças russas, lideradas sem nenhuma competência, equipadas e treinadas de forma inadequada, suscitou uma forte comoção no país (MIÉVILLE, 2017).

No dia 9 de janeiro a greve iniciada na Metalúrgica Putilov culminou numa imensa procissão operária em direção ao Palácio de Inverno. À frente demais de 150.000 manifestantes, o padre Gapon entregaria ao czar Nicolau II uma solicitação que exigia a reincorporação dos colegas demitidos, a melhoria das condições sanitárias, a redução da jornada de trabalho para 8 horas diárias, entre outras reivindicações. A manifestação poderia ter sido facilmente controlada através de uma negociação, mas a estupidez das autoridades produziu uma carnificina, deixando cerca de 3 mil feridos e 2 mil cadáveres, cujo sangue espalhado na neve deu a esse dia o nome de "domingo vermelho" ou "domingo sangrento".

O impacto foi incalculável, desencadeando uma mudança radical nas atitudes dos trabalhadores. O domingo sangrento apressou a revolução. A greve geral continuou por vários dias em São Petersburgo e se estendeu, ao longo das semanas seguintes, a várias cidades e regiões do Império 
Russo. Em meio a isso, ocorreram novos confrontos e, com eles, mais mortes, 500 em Lodz e 90 em Varsóvia (MIÉVILLE, 2017). No momento em que o movimento chegou, finalmente, a Moscou, os operários tiveram a ideia de promover, pelas fábricas da cidade, a eleição de um comitê representativo, que foi batizado de soviet (conselho) dos delegados operários (ACHCAR, 2009, p. 72). O primeiro soviete surgiu, portanto, na capital.

Segundo Achcar (2009, p. 72), a onda de greves de janeiro e fevereiro foi seguida por outra na primavera, durante a qual os operários têxteis de Ivanovo-Voznesensk, a "Manchester russa", situada na região de Moscou, em greve desde o dia 12 de maio, criaram, três dias mais tarde, com 151 membros, um soviete de delegados operários que os historiadores passaram a considerar, injustamente, o primeiro.

Para Anweiler (1975), apesar de alguns grupos, como os mencheviques e socialistas-revolucionários, terem propagandeado a criação dos sovietes em 1905, sua influência era tão pequena entre as massas trabalhadoras que seria bastante duvidoso atribuir-lhes a responsabilidade por sua origem. Nessa mesma direção, Broué comenta que os sovietes de 1905 não foram organizados por alguma tendência do movimento operário, sendo muito mais o resultado da necessidade de os trabalhadores terem uma organização de massa que aglutinasse toda a classe para dirigir a greve geral daquele ano (BROUÉ, [197-], v. 1, p. 102). Segundo Broué, os revolucionários russos que mais simpatizavam com os sovietes em 1905 os consideravam, no melhor dos casos, como meros instrumentos auxiliares do partido. Nem mesmo os bolcheviques, vanguarda da revolução de 1917, compreenderam o importante papel que havia sido desempenhado pelos sovietes em 1905. Assim, depois da dissolução do soviete de Petrogrado, com a derrota do proletariado na Revolução de 1905, os bolcheviques reduziram os sovietes a uma mera organização de luta, mas nunca como algo parecido a um parlamento operário ou um órgão do autogoverno proletário.

Esse caráter espontâneo dos sovietes de 1905. espontâneo no sentido de não terem sido cria- dos por nenhuma organização, não impediu que eles assumissem o papel de órgãos dirigentes do movimento revolucionário, que se estendeu por todo o ano de 1905. Anweiler (1975, p. 68) comenta que o soviete de Moscou e os conselhos de bairros a ele ligados ditaram uma série de ordens, regulando, dentre outras coisas, a distribuição da água e a abertura de negócios de produtos indispensáveis. A força dos sovietes era tão grande que eles começaram a dominar diversas cidades russas. Em Novorossijsk, por exemplo, situada na região portuária de Krasnodar, ponto chave para o acesso ao Mar Negro, foi conquistada pelo soviete da cidade, quando as tropas se recusaram a cumprir as ordens de atirar contra o povo, forçando o prefeito e o chefe de polícia a fugirem. Diante dessa instável situação que se generalizava em várias cidades, os editores do jornal conservador Novoe Vremja (Nova Hora) afirmavam, aflitos:

\begin{abstract}
Encontramo-nos possivelmente às vésperas de uma monstruosa rebelião [...] Este governo revolucionário [...] já fala sem rodeios dos meios da luta armada. Isto já não é uma atividade clandestina. Ao contrário, clandestino parece converter-se o trabalho do velho poder (apud ANWEILER, 1975, p. 66).
\end{abstract}

O alerta desesperado dos conservadores deixa claro o significado do duplo poder. Como indicaram Marx e Engels, os sovietes estavam sendo construidos ao lado dos governos oficiais, substituindo-os em diversas cidades. O poder proletário representado nos sovietes foi ganhando força na conquista e controle dos meios de produção e das administrações locais, isolando o antigo governo e os patrões.

Os sovietes de 1905 eram compostos por delegados de trabalhadores com mandatos revogáveis a qualquer momento, eleitos pelo conjunto de trabalhadores organizados ou não em sindicatos e partidos. Os sovietes acabavam funcionando como autoridades revolucionárias que exerciam um poder antagônico ao lado do Estado czarista, um duplo poder de fato, que se apoiava na autoridade dos trabalhadores, geralmente reprimida pelas outras classes da sociedade (TROTSKY apud BROUÉ, [197-], v. 1, p. 103). 
Em 7 de dezembro, ou seja, 11 meses depois do "domingo sangrento", uma greve geral em Moscou se transformou em insurreição urbana, respaldada pelos Socialistas Revolucionários e pelos bolcheviques. Durante vários dias a cidade permaneceu nas mãos dos revolucionários. Mas o apoio dado ao governo pelo Regimento Semiónov, de São Petersburgo, bombardeando os tecelões insurgentes e matando 250 deles, eliminou as últimas forças da Revolução de 1905. A repressão à insurreição deixou quase um milhão de mortos e vários milhares de feridos, entre os insurgentes e a população (ACHCAR, 2009, p. 80). Um dos lemas dos trabalhadores era "melhor ser derrubado numa pilha de ossos do que viver como escravo" (MIÉVILLE, 2017, p. 37-38).

Dos 51 membros do soviete de São Petersburgo que passaram pelos tribunais, 15 foram condenados à deportação perpétua na Sibéria. Essa derrota impôs uma cicatriz inesquecivel na classe trabalhadora russa, marcando sua memória com a certeza de que o combate contra o regime czarista era totalmente legítimo (ACHCAR, 2009, p. 80-81).

Um dos motivos da derrota dos trabalhadores na Revolução de 1905 pode ter sido a imaturidade da direção revolucionária, que, embora tivesse disposição em começar a luta decisiva pelo poder, carecia de suficiente experiência e influência na classe operária, elemento essencial em qualquer revolução vitoriosa. Para citar um exemplo, o Partido Operário Social-Democrata Russo, fundado sete anos antes, em 1898, ainda estava, por assim dizer, curando as cicatrizes do racha entre bolcheviques (maioria) e mencheviques (minoria) ocorrido durante o ll Congresso, em 1903. Broué comenta que a árida luta de classes da década seguinte, que manteve diversos dirigentes revolucionários presos ou exilados, foi responsável por forjar uma direção revolucionária capaz de cumprir a sua missão histórica de contribuir com a classe trabalhadora na conquista do poder.

\section{Os sovietes russos em 1917}

Os sovietes reapareceram na Rússia doze anos depois, em 1917. Contudo, as origens dos sovietes de 1905 e 1917 são diferentes: o soviete dos deputados operários de 1905. primeiro ancestral do sistema, nascera da greve geral. Representava diretamente as massas em luta. Os cabeças da greve tornavam-se deputados do soviete. A seleção dos efetivos era feita ao fragor dos canhões (TROTSKY, 1977, v. 1, p. 192).

A Revolução de Fevereiro de 1917, ao contrário, "venceu antes que os operários tivessem constituido os seus sovietes" (TROTSKY, 1977, v. 1, p. 192). Nessa época,

\begin{abstract}
os verdadeiros chefes operários ainda não haviam abandonado as ruas, ora desarmando uns, ora armando outros, e consolidando, assim, a vitória, ficatam alarmados com as informações que anunciavam a criação, no Palácio de Táuride, de um certo Soviete de deputados operários (TROTSKY, 1917, v. 1, p. 192).
\end{abstract}

Esses sovietes de fevereiro de 1917, criados pelas costas dos verdadeiros chefes operários, foi obra de oportunistas que se mantinham "à margem da luta revolucionária, Imas que estavam] dispostos, todavia, à colheita dos frutos" (TROTSKY, 1977, v. 1, p. 192). Provavelmente Trotsky estava se referindo à reunião feita por Gvózdiev, Bogdávnov e seus colegas. Segundo Miéville (2017, p. 64), as massas trabalhadoras desconfiavam daquele organismo nascente, fruto da imaginação de socialistas à sua direita. É duvidoso, portanto, estabelecer uma regra geral para a criação e o para o papel dos sovietes.

De acordo com Anweiler (1975, p. 136), em fevereiro de 1917, por trás do governo provisório estavam a burguesia russa e a aristocracia liberal, enquanto o soviete de Petersburgo e os conselhos de soldados e operários nas províncias representavam o proletariado urbano e os soldados do exército, dirigidos ainda por uma radical intelectualidade pequeno-burguesa (mencheviques e socialistas revolucionários).

Um dos membros da Duma (a assembleia legislativa), o conservador Chulguin, resumiu a situação da Rússia em fevereiro de 1917 da seguinte maneira: se não assumirmos o poder. outros assumirão, aqueles que já elegeram certos patifes nas fábricas. Quem Chulguin temia? Os sovietes de operários, soldados e camponeses. Começava, assim, a tumultuada coexistência dessas duas políticas, filosofias e forças sociais conflitantes e sobrepostas (MIÉVILLE, 2017, p. 67). 
A descrição do palácio nesses dias de fevereiro dá uma ideia clara do caos instalado nos primeiros dias da insurreição de fevereiro:

Os saguões do Palácio de Táuride, normalmente um local de burocracia impecável, que nunca era perturbado por algo mais caótico ou desordenado que um memorando caído no chão, agora haviam se tornado um alojamento militar. No Salão Circular jazia o cadáver de um soldado. Centenas de camaradas vivos acamparam nos corredores do palácio, acocorados ao lado de fogões improvisados, bebendo chá, fumando e esfregando os olhos, prontos para enfrentar a contrarrevolução que todos temiam estivesse chegando. Os corredores fediam a pólvora, suor e excremento. Os escritórios se transformaram em depósitos de armas e comida. Uma grande sala de reuniões estava cheia de sacos de cevada saqueados. Ao lado deles, um porco morto sangrava (MIÉVILLE, 2017, p. 67-68).

Nas ruas de Petrogrado a situação era ainda mais desesperadora para as classes dominantes. Os trabalhadores pilhavam armas dos armazéns do regime para defender as fábricas, organizavam-se em grupos armados, quase todos jovens, quase todos radicais e furiosos, não raro politicamente incoerentes. O soviete começou a coordenar aqueles grupos, organizando uma milicia de trabalhadores para restabelecer e manter a ordem. Também criou uma comissão para regular o abastecimento de comida. Em breve autorizaria o retorno de determinados jornais (MIÉVILLE, 2017, p. 65).

Como exigia Chulguin e seus comparsas, a Duma acabou assumindo o poder, submetendo os sovietes a seu comando. Kerenski, chefe do governo provisório, conseguiu convencer a maioria moderada do soviete a subordinar a sua comissão militar à Duma. Ao receber a autorização do soviete, a comissão militar da Duma imediatamente deu aos soldados amotinados a ordem de retornarem às suas guarnições e reconhecerem a autoridade de seus comandantes, (MIÉVILLE, 2017. p. 68-69) para tentar, assim, apaziguar a situação. Muitos soldados não tinham a menor confiança na Duma e estranhavam a vacilação do soviete (MIÉVILLE, 2017, p. 72). Nesse momento, o soviete de Petrogrado era ainda dominado pelos mencheviques e a fração moderada dos Socialistas-Revolucionários. Os bolcheviques, a ala esquerda dos Socialistas Revolucionários e outros grupos revolucionários menores tinham, juntos, menos de $10 \%$ dos representantes do soviete (MIÉVILLE, 2017, p. 44). Nas províncias menores, a correlação de forças era a mesma, expressa no congresso dos sovietes realizado de 3 a 24 de junho: 285 delegados eram socialistas-revolucionários, 248 mencheviques e somente 105 bolcheviques, além de alguns pequenos grupos socialistas, além de 73 independentes (ANWEILER, 1975, p. 131). Como se vê, não basta construir os sovietes. $O$ fundamental é a sua composição política.

Os comitês ou conselhos de fábrica de Petersburgo, no entanto, estavam muito mais radicalizados que os sovietes, tendo ali os bolcheviques o domínio quase absoluto. No congresso dos comitês de fábrica o controle operário proposto pelo bolchevique Zinoviev foi aprovado por 297 votos, com 21 votos contrários e 44 abstenções (ANWEILER, 1975, p. 134). Comparados com os comitês de fábrica, os sindicatos não possuiam maior influência em 1917. Dirigidos em sua maioria por mencheviques, os sindicatos se opunham a intervenções diretas e radicais na produção. Além disso, representavam sempre apenas uma parte dos trabalhadores.

A composição conservadora dos sovietes de toda a Rússia mostra que se o duplo poder já estava se construindo nas fábricas ocupadas pelos operários e nas guarnições dominadas pelos soldados, na instância política o duplo poder ainda não tinha se desenvolvido, pois o soviete encontrava-se ainda politicamente muito próximo do governo provisório, permanecendo totalmente submetido a ele. Por isso, no mês de junho de 1917, Lênin propôs que não se agitasse mais a palavra de ordem "Todo o Poder aos Sovietes" proposta por ele próprio nas Teses de abril, argumentando que os socialistas moderados do soviete se recusavam a tomar o poder em suas mãos, mesmo que viesse de bandeja. De fato, o presidente da fração socialista revolucionária considerava que tentar derrubar o governo provisório seria uma aventura, enquanto o menchevique Liber dizia que o soviete não tomava o poder não porque não podia, mas porque não queria. Para esses grupos, o soviete não poderia virar as costas 
para a burguesia, uma vez que a etapa da revolução, segundo eles, era democrático-burguesa. Foi esse o espírito da resolução do I Congresso dos Deputados Operários e Soldados, aprovada por ampla maioria (543 votos a favor, 126 contra e 52 abstenções) (ANWEILER, 1975, p. 148-149).

O problema central, segundo Lênin, era que os bolcheviques ainda não tinham o apoio suficiente dos trabalhadores no soviete. A prioridade era, antes de tudo, aumentar a influência do partido no soviete. Isso não tardou a acontecer. Em julho, quando os trabalhadores e os soldados organizaram um levante em Petrogrado, o soviete, vacilante, não exigia a saida imediata da Rússia da guerra, uma legitima aspiração da classe trabalhadora. Em agosto, quando o general Kornilov, ministro da Guerra de Kerenski, organizou um golpe contra seu próprio governo, foram os bolcheviques que enfrentaram os golpistas, defendendo, na prática, o governo provisório dominado pelos socialistas-revolucionários e pelos mencheviques mais do que eles mesmos. Kerenski, o chefe do governo provisório, conciliava com o golpista Kornilov por preferir este aos bolcheviques. A consequência desses episódios foi o crescimento vertiginoso do partido bolchevique.

A eleição da Duma em 20 de agosto dá uma ideia da nova situação. Os bolcheviques tornaram-se o segundo maior partido na Assembleia Legislativa, com 184 mil votos, deixando para trás os kadetes (partido burguês), com 114 mil votos e os mencheviques, com ridiculos 24 mil, perdendo apenas para os socialistas-revolucionários, que, por representarem a classe social mais numerosa da Rússia, os camponeses, receberam 205 mil votos (MIÉVILLE, 2017, p. 209). Essa tendência de fortalecimento dos bolcheviques se aprofundou nos dias seguintes. Um mês depois, em 24 de setembro, o presidium do soviete de Petrogrado passou para as mãos do partido de Lênin. Dos sete membros, quatro eram bolcheviques, dois Socialistas-Revolucionários e apenas um menchevique.

Finalmente, a hora do choque entre dois regimes, o burguês e o proletário, havia chegado na instância representativa. O duplo poder havia se generalizado. O soviete não era mais um mero apêndice do governo provisório, mas a expressão do espírito de luta dos operários, dos soldados e dos camponeses, que ocupavam fábricas e terras e saqueavam os quartéis em busca de armas. Finalmente os trabalhadores tinham construido um organismo que, de fato, os representava. Havia chegado o momento de derrubar o governo provisório e transferir "Todo o Poder aos Sovietes". Se os bolcheviques não tomassem o poder, essa oportunidade histórica poderia ser perdida. Os alemães se aproximavam de Petrogrado, com certa conivência de grupos capitalistas: "melhor ser dominado pelos alemães do que pelos bolcheviques", (MIÉVILLE, 2017) diziam alguns. Além disso, o Congresso dos Sovietes estava marcado para o dia 25 de outubro. Havia sérios riscos de o Congresso não aprovar a insurreição, dando continuidade às tentativas de conciliação entre os sovietes e o governo provisório, o que significava conservar a Rússia na guerra, mantendo a situação de fome e miséria da população, à espera de uma Assembleia Constituinte que teria, muito provavelmente, uma composição conservadora. Outro motivo que tornava urgente a conquista do poder pelo soviete era a falta de controle da situação social. Na ausência da autoridade proletária, a criminalidade ocupava o espaço. Assassinatos, execuções, linchamentos tornavam-se cotidianos (MIÉVILLE, 2017, p. 249250). Por todas essas razões, Lênin defendia a imediata conquista do poder pelos sovietes. A insurreição deveria, segundo ele, ocorrer antes do Congresso dos Sovietes, forçando-o apenas a referendar um fato já consumado. A insurreição ocorreu na madrugada do dia 25 de outubro. 0 Congresso iniciou em meio à insurreição.

Como se vê, nem sempre os sovietes são a solução para os desafios da revolução. Não basta construir os sovietes. O determinante é a sua composição interna. De fevereiro a julho de 1917. os sovietes estavam muito aquém do espírito de luta dos trabalhadores. Enquanto os sovietes conciliavam com o governo provisório, os operários, os soldados e os camponeses lutavam nas ruas, nas fábricas, no front e nos campos, exigindo o fim da participação russa na guerra, a transferência 
de terra aos camponeses e a reorganização do abastecimento dos meios de subsistência. De fevereiro a julho, os sovietes e o governo provisório já haviam se mostrado incapazes de resolver esses três problemas fundamentais, expressos na palavra-de-ordem bolchevique "pão, paz e terra". Ambos estavam aquém das massas trabalhadores. O duplo poder não significa apenas construir organizações proletárias ao lado do governo burguês. Depende da sua direção. Se não fosse a atuação dos bolcheviques, o futuro dos sovietes tenderia a confirmar a hipótese de Kerenski, confidenciada a um embaixador inglês em maio de 1917: "os sovietes morrerão de morte natural" (ANWEILER, 1975, p. 150). É provável que, se não fosse a intervenção enérgica dos bolcheviques para realizar a insurreição, o futuro dos sovietes teria sido esse previsto por Kerenski. Deve-se, portanto, evitar o que Trotsky chamou de "feitiço sovietista", ou seja, evitar ser enfeitiçado pelas formas organizativas, quaisquer que sejam. O papel das organizações depende de sua composição interna, depende de sua direção.

Essa rica experiência histórica da Revolução Russa, baseada na concepção de duplo poder exposta por Marx e Engels, foi recuperada como teoria programática nos quatro primeiros congressos da Internacional Comunista, fundada em 1919.

\section{O duplo poder segundo os quatro primeiros congressos da Internacional Comunista}

Nas teses dos quatro primeiros congressos da Internacional Comunista há indicações claras para que a classe trabalhadora dos outros paises siga o que a classe fez na Rússia, a chamada via soviética da revolução mundial, a construção de organismos duais de poder. Por exemplo, a tese intitulada "A Internacional Comunista e a Internacional Sindical Vermelha" do III Congresso defendia a ocupação das fábricas quando seus proprietários decidissem fechá-las. "De forma alguma", afirmava a tese, "será tolerado que os operários sejam mandados para a rua sem que a empresa se ocupe deles" (TESIS..., 2017, p. 178). A ocupação das fábricas visava conservar os empregos. Ela era descrita, portanto, como uma luta defensiva. Para organizar as ocupações, a tese defendia que fossem formadas Comissões Especiais de Controle, cuja função seria a de investigar "sobre as matérias primas, o combustivel, os pedidos [(...)] os recursos financeiros depositados nos bancos [...], além das vinculações entre as empresas no sentido de suprimir o segredo comercial" (TESIS..., 2017, p. 178).

Essas formas de luta (ocupações de fábrica) e formas de organização (organismos de controle operário) já representam o aprofundamento da dualidade de poder num momento de profunda instabilidade econômica e política. O choque entre o caduco poder burguês e o nascente poder proletário revolucionário é inevitável. Não há dúvida de que a burguesia reprimirá com vigor a constituição do duplo poder, atacando os organismos criados pelos trabalhadores e as fábricas por eles ocupadas. Nesse sentido, a "resolução sobre a tática da Internacional Comunista" exposta no IV Congresso observa que "a mera tentativa do proletariado de formar um governo operário enfrentará desde o começo a resistência mais violenta da burguesia" (TESIS..., 2017, p. 206-207). Como se vê, o duplo poder expõe a violência burguesa, antes oculta. A "Tese sobre a tática" do III Congresso indica que, para se defender dos ataques dos capitalistas, os trabalhadores devem se apoiar "nos melhores e mais ativos elementos nas empresas e nos sindicatos para criar sua própria tropa operária e suas próprias organizações de combate com o objetivo de resistir aos ataques fascistas". (TESIS..., 2017, p. 139). Conforme o trecho, o proletariado se arma para se defender, para "resistir aos ataques" da burguesia. Não é ele que toma a iniciativa da violência. O proletariado apenas ocupa as fábricas para garantir o seu emprego. A violência provém da reação burguesa.

Quando, finalmente, os sovietes são criados, é sinal de que se alcançou o momento culminante do processo de dualidade de poder. Segundo a "Tese sobre a tática" do III Congresso, os sovietes são as organizações que unificam todo o proletariado. Mas eles só serão capazes de realizar esta tarefa se surgirem da luta pelos objetivos econô- 
micos comuns dos mais amplos setores operários, se criarem vínculos entre todos os setores revolucionários do proletariado: o partido revolucionário, os comitês operários revolucionários e aqueles sindicatos que estão se desenvolvendo do ponto de vista revolucionário. Somente por meio da criação de organizações industriais desse tipo, por sua vinculação nos ramos da indústria e nos centros industriais, a luta das massas operárias poderá adquirir uma unidade orgânica, somente assim se conseguirá diminuir a influência da social-democracia e dos chefes sindicais sobre os trabalhadores (TESIS..., 2017, p. 135).

Comissões de Controle da Produção, Organismos de Combate e Sovietes: essa é, de maneira sintética, a forma como o Estado Operário se organiza, ainda que de forma embrionária, nos períodos de dualidade de poder, de acordo com os membros dos quatro primeiros congressos da Internacional Comunista, iluminados pela experiência da Revolução Russa e pela teoria programática de Marx e Engels. O novo Estado em gestação somente nascerá definitivamente e se desenvolverá quando o duplo poder for superado e a antiga classe dominante for obrigada a se submeter ao novo poder proletário. Somente então, depois dessa gestação chamada duplo poder, nascerá a nova sociedade, gerada no ventre da velha sociedade capitalista, que, através de suas próprias contradições internas, criou as condições para a sua superação.

Se a estratégia da revolução socialista mundial enquanto dualidade de poder estava clara, em linhas gerais, desde Marx e Engels, sendo aplicada pelos bolcheviques na Rússia de 1917, ganhando determinações programáticas mais precisas nos quatro primeiros congressos da Internacional Comunista, ela acabou caindo no esquecimento, ${ }^{2}$ sendo soterrada pelas mais diversas formas de revisões e supostas atualizações da teoria de Marx e Engels. Algumas destas revisões passaram a questionar o caráter universal da estratégia baseada na dualidade de poder.

\section{O duplo poder é um fenômeno universal?}

Ainda no início do século $X X$, menos de uma década após a vitória da Revolução Russa, iniciou no interior do marxismo um debate a respeito da universalidade ou não da estratégia baseada no duplo poder, a chamada via soviética. Um dos precursores desse debate foi o marxista italiano Antônio Gramsci. Depois da ascensão do fascismo na Itália em 1922, Gramsci considerou que a derrota do proletariado em diversos países do Ocidente, como a Itália, a Alemanha e a Hungria, teria sido consequência do programa baseado na dualidade de poder ou, usando suas palavras, do programa baseado na guerra manobrada (ou guerra de movimento), ou ainda da estratégia baseada no "ataque frontal" ao poder. Assim afirma Gramsci, no parágrafo 138 do caderno 6, escrito entre 1930 e 1932 (2004, v. 3. p. 255), ao criticar Bronstein, pseudônimo usado para Trotsky:

a questão de teoria política mais importante posta pelo periodo do pós-guerra e a mais dificil de resolver corretamente (é aquela) ligada às questões levantadas por Bronstein, que, de um modo ou de outro, pode ser considerado o teórico político do ataque frontal num período em que este é apenas causa de derrotas.

Há, nessa afirmação de Gramsci, algo indiscutivelmente certo: Trotsky continuou, até o fim da vida, defendendo o programa baseado na dualidade de poder. ${ }^{3}$ Basta ler o Programa de Transição, escrito em 1938, dois anos antes de seu assassinato no México, para encontrar ali uma teoria programática baseada na construção de um processo de duplo poder.

A estratégia da dualidade de poder, que Marx e Engels associaram à noção de Revolução Permanente, teria tido, segundo Gramsci, um caráter universal no Ocidente somente até 1870. Isso porque na época de Marx e Engels

não existiam ainda os grandes partidos politicos de massa e grandes sindicatos econômicos, e a sociedade ainda estava sob muitos aspectos, por assim dizer, no estado de fluidez [...] Já no periodo posterior a 1870, com a expansão colonial europeia [...] as relações 
de organização internas e internacionais do Estado tornam-se mais complexas e robustas (GRAMSCl, 2004, v. 3, p. 24).

Gramsci não deixa clara a razão de ele ter estabelecido este ano de 1870 como marco divisório. Provavelmente trata-se do Risorgimento, um movimento de unificação nacional que se estendeu de 1815 a 1870, quando a península Itálica viria a ser submetida a um único Estado, periodo que coincidiu também com a unificação da Alemanha.

A partir de 1870, o Estado dos países avançados ocidentais havia se tornado mais complexo, exigindo uma série de mediações naquilo que Gramsci chamou de guerra de posição, baseada na conquista da hegemonia nos novos organismos da sociedade civil, que teriam algum vínculo, maior ou menor, com o Estado burguês. A partir de então (1870), a dualidade de poder só poderia obter êxito nos países atrasados do Oriente, como ocorreu na Rússia em 1917. Já nos países avançados do Ocidente, a estratégia da dualidade de poder teria apenas uma importância parcial. Nas palavras de Gramsci: "o elemento (da guerra de) movimento, que antes constituía 'toda' a guerra, torna-se apenas "parcial'" (GRAMSCl, 2004, v. 3 . p. 24). Ou seja, a guerra de movimento, aquela baseada no "ataque frontal ao poder" (2004, v. 3. p. 255), ou, em outras palavras, a estratégia baseada na dualidade de poder, não seria mais o eixo central da estratégia revolucionária nos países avançados do Ocidente. Estava lançada, assim, a polêmica a respeito da universalidade ou não da dualidade de poder. Segundo Gramsci, as novas instituições existentes no Ocidente a partir do último quarto do século XIX, como os sindicatos de massa, as associações profissionais etc., impediam a aplicação da dualidade de poder (o que ele chama de ataque frontal ao poder) como estratégia central da luta do proletariado, tendo, no máximo, um caráter parcial. Mais importante do que preparar o ataque frontal ao poder, ou seja, criar e desenvolver os organismos duais de poder, seria, segundo Gramsci, conquistar, através da guerra de posição, a hegemonia nos organismos da sociedade civil, como sindicatos, associações etc. Utilizar a estratégia baseada no ataque frontal como eixo central como continuou defendendo Trotsky seria, segundo Gramsci, a causa de derrotas no Ocidente. Ou seja, conquistar a direção de sindicatos, de associações de moradores, de associações profissionais etc., tornou-se mais importante no Ocidente, na concepção programática de Gramsci, do que construir os organismos duais de poder.

Cerca de 10 anos antes de Gramsci redigir seus Cadernos na prisão fascista, Lênin defendia, em diversas oportunidades, o caráter universal da dualidade de poder, em sentido contrário ao marxista italiano. Em 1919, no Congresso de fundação da Internacional Comunista, no "Discurso sobre as suas teses", Lênin afirmou: "Ficou demonstrado mais uma vez que o curso geral da revolução proletária é idêntico em todo o mundo [...]. Primeiramente a constituição espontânea, elementar, dos sovietes, depois a sua ampliação e desenvolvimento" (TESIS..., 2017, p. 30). Diante disso, proclamava Lênin, sem deixar margem à dúvida em relação a sua posição: "a propagação do sistema dos sovietes é para nós e particularmente para a maioria dos países da Europa ocidental, a mais essencial das tarefas" (TESIS..., 2017, p. 30). No ano seguinte, em 1920, na célebre obra "Esquerdismo: doença infantil do comunismo", Lênin continua defendendo a mesma posição ao afirmar que

\begin{abstract}
agora, no mundo inteiro, surgiu a ideia do poder dos Sovietes, que se espalha com uma rapidez prodigiosa entre o proletariado de todos os paises [...]. A experiência demonstrou que, em certas questões fundamentais da revolução proletária, todos os paises passarão inevitavelmente por onde passou a Rússia (LÊNIN. 1978, p. 135, grifo do autor).
\end{abstract}

Se antes da prisão Gramsci havia sido, na condição de editor do jornal A Nova Ordem, um entusiasta defensor da dualidade de poder, orientando os operários de Turim a construir seus comitês de fábrica e controlar a produção, seguindo os passos dos bolcheviques, ${ }^{4}$ depois da

4 A esse respeito, ler Gramsci (2004b) e comentários em Dillenburg (2011). 
prisão Gramsci revê sua posição. Nesse sentido, Gramsci teria que acrescentar Lênin à acusação feita a Trotsky de defender a tática do ataque frontal nos paises ocidentais quando esta era somente a causa de derrotas. Mas claro que Gramsci não fez isso. Ao contrário, procurou se aproximar de Lênin, ao afirmar: "parece-me que Ilich havia compreendido a necessidade de uma mudança da guerra manobrada (de movimento), aplicada vitoriosamente no Oriente em 1917, para a guerra de posição, única possivel no Ocidente". E conclui Gramsci: "Parece-me este o significado da fórmula da 'frente única'" (GRAMSCl, 2004, v. 3, p. 262). Como vimos, tanto no I Congresso da Internacional Comunista quanto no Esquerdismo... não há sinal de mudança na perspectiva de Lênin. É claro que Lênin, assim como a Internacional Comunista em seus quatro primeiros congressos, defendeu a noção de frente única proletária. Assim como Gramsci, Lênin defendia que os bolcheviques deveriam atuar em ações frentistas com outras organizações. ${ }^{5}$ Mas Lênin não subordinava a construção dos sovietes à criação de frentes proletárias, como propôs Gramsci nos Cadernos. Portanto, não parece haver uma maneira de seguir, ao mesmo tempo, o Gramsci dos Cadernos do Cárcere, por um lado, e Lênin, por outro, no que se refere à estratégia revolucionária. É preciso escolher uma das duas estratégias. Na questão do programa, as propostas são inconciliáveis: uma organização com influência gramsciana transformará o duplo poder em mais uma tática dentre tantas outras, submetendo-a à estratégia de disputar as direções das organizações da chamada sociedade civil; em outra direção, a estratégia defendida por Lênin colocará como eixo central de sua ação a construção de organismos duais de poder, submetendo a necessária constituição de frentes proletárias nos mais amplos espaços à estratégia baseada no duplo poder.

Embora a proposta programática do Gramsci dos Cadernos seja incompativel com a de Lênin, há algo em comum em relação às suas premissas: para ambos, o surgimento e desenvolvimento dos sindicatos e associações de massa, aquelas chamadas por Gramsci de organizações da sociedade civil, passam a dificultar a realização prática da dualidade de poder como eixo central da estratégia revolucionária. Vimos que esta é uma preocupação de Gramsci. Na mesma época, Lênin chega a uma conclusão semelhante ao traçar uma trajetória histórica dos sindicatos:

no principio do desenvolvimento do capitalismo
[.... os sindicatos representaram um progresso
gigantesco da classe operária. Marcaram a
passagem do estado de dispersão e de impo-
tência em que se encontravam os operários,
para os primeiros esboços do agrupamento
de classes (LÊNIN, 1978, p. 155, grifo do autor).

Lênin adverte, em seguida, que com o desenvolvimento do capitalismo e o consequente

\begin{abstract}
desenvolvimento da forma superior da união de classe dos proletários, o Partido Revolucionário do Proletariado [...], os sindicatos revelaram inevitavelmente certos traços reacionários. certa estreiteza corporativa, certa tendência para o apoliticismo, certo espírito rotineiro, etc. (LÊNIN, 1978, p. 155, grifo do autor).
\end{abstract}

Percebe-se a semelhança das duas concepções em relação ao papel reacionário que os sindicatos tendem a desempenhar na fase superior do capitalismo, a chamada fase imperialista, segundo Lênin, e os países avançados do Ocidente, para Gramsci.

Assim como Lênin, Rosa Luxemburgo também advertiu para a tendência à burocratização dos sindicatos:

a especialização de sua atividade profissional
como dirigentes sindicais, além do horizonte
naturalmente estreito que acompanha as lu-
tas isoladas de uma etapa pacifica, facilitam
muito a tendência dos funcionários sindicais
à burocratização e à estreiteza de perspectiva
[.... A sobrevivência da organização converte-se
gradualmente de meio em fim, em algo precio-
so ao qual se devem subordinar os interesses
da luta (LUXEMBURGO, 1974, p. 103).

Analisando o que ocorreu nas revoluções russas de 1905 e 1917, pode-se interpretar que a ausência de sindicatos de massa estimulou

5 Ver Esquerdismo, doença infantil do comunismo, particularmente o capítulo VIII, intitulado "nenhum compromisso?" (LÊNIN, 1978). 
os trabalhadores a criar organismos duais de poder que unificassem as diversas categorias profissionais em luta. Nesse sentido, não seria absurdo afirmar que a ausência de sindicatos de massa potencializou a dualidade de poder na Rússia. O proletariado russo não precisava se preocupar em disputar os aparelhos sindicais, associações etc., porque eles ainda não possuiam tanta influência na Rússia do início do século XX. Por isso, o proletariado russo pôde se dedicar imediatamente a construir os organismos do futuro Estado operário.

As revoluções proletárias na Rússia não foram as primeiras nem as últimas que protagonizaram processos de dualidade de poder. Vejamos, então, algumas dessas experiências históricas.

\section{Outras manifestações da dualidade de poder}

Dentre as revoluções proletárias anteriores, a Comuna de Paris ganha, sem dúvida, enorme destaque. Vejamos, então, como foi construido o duplo poder pelos communards de Paris. Lênin observa que, assim como na Revolução Russa, na Comuna de Paris a questão da propriedade privada dos meios de produção era a questão central. Uma das primeiras resoluções da Comuna estabeleceu que "todas as fábricas e oficinas abandonadas ou paralisadas por seus donos fossem entregues às cooperativas operárias, com o fim de retomar a produção" (LÊNIN, 1977, p. 132). A Comuna procurava instaurar, assim, segundo Lênin, um legítimo governo proletário. Enquanto o duplo poder ia se instalando na instância das fábricas, o mesmo acontecia na instância política. Nesse sentido, Basotti comenta que de março a maio de 1871, enquanto Paris vivia a revolução operária, Versalhes operava a contrarrevolução burguesa, caracterizando uma típica situação de duplo poder (BASOTTI, 2020).

Se a Comuna de Paris representa os antecedentes da dualidade de poder em relação à Revolução Russa, após 1917 a dualidade do poder ocorreu, em maior ou menor grau, na Alemanha, na Hungria, na França e na Espanha. Em todos estes levantes, no entanto, o proletariado foi derrotado.

Dentre as revoluções burguesas, tanto a chamada "Revolução Gloriosa" na Inglaterra do século XVII quanto a Revolução Francesa do século XVIII criaram situações de duplo poder. $\mathrm{Na}$ Glorious Revolution, o duplo poder se deu entre a burguesia e a realeza: "o governo da burguesia era o Parlamento presbiteriano apoiado na City londrina (enquanto) o poder real se apoiava nas classes privilegiadas ou nas suas cúpulas, aristocratas e bispos" (TROTSKY, 1977, p. 186). Na Revolução Francesa, por sua vez, um dos polos da dualidade de poder estavam na Assembleia Nacional, representante da burguesia depois da tomada da Bastilha pelo povo. O outro polo encontrava-se na velha monarquia, apoiada pela alta nobreza, pelo clero, pela burocracia e pela casta militar (TROTSKY, 1977, p. 187). Como se vê, o duplo poder não é uma exclusividade das revoluções proletárias. Ele faz parte de uma história anterior às revoluções socialistas.

Mas a ideia de um governo dos conselhos de trabalhadores, que poderiam servir de inspiração aos sovietes russos, é muito mais antiga, remetendo-nos a cerca de 2.400 anos atrás, aos célebres Diálogos, de Platão. No diálogo "Leis", considerado o diálogo final na temporalidade da lexis, ${ }^{6}$ um anônimo ateniense defende um governo dos conselhos de soldados, que formarão "um corpo de juizes, a saber, hoplitas, cavaleiros e cada um dos outros ramos, e convocar-se-á hoplitas perante hoplitas, cavaleiros perante cavaleiros e todos os outros de maneira análoga diante de soldados de sua mesma classe" (PLATÃO, 2010, p. 475 apud BENOIT, 2017, p. 523). Na proposta do ateniense, combatentes de vários tipos elegeriam entre si seus próprios representantes ao conselho de juizes. Como não encontrar semelhanças nesses tribunais de soldados armados defendidos pelo ateniense dos Diálogos, de Platão, e os sovietes de soldados, operários e camponeses da Revolução Russa? Os soldados russos, que desertaram do front da I Guerra para se unir aos operários e

$6 \quad$ A esse respeito, ver Benoit (2015). 
camponeses, ao votarem nos sovietes erguendo suas armas, estavam, sem saber, retirando do esquecimento ${ }^{7}$ seus companheiros de mais de dois milênios atrás, os hoplitas e cavaleiros gregos. A semelhança entre a proposta do velho ateniente do diálogo Leis e os sovietes russos fica ainda mais clara quando esse anônimo personagem defende que quando soldados e trabalhadores formam um governo e passam a decidir o destino da cidade, este governo está prestes a realizar "a antiga máxima, na qual se afirma: são verdadeiramente comuns os bens dos philoi" (PLATÃO, 2010, p. 216 apud BENOIT, 2017, p. 478). Como se vê, a noção de um governo dos conselhos de trabalhadores associado a uma sociedade na qual todos os bens sejam comuns, ou seja, uma sociedade comunista, faz parte da longa tradição dialética, método fundado por outro personagem anônimo criado por Platão, o Estrangeiro de Eleia do Diálogo Sofista (PLATÃO, 1991). ${ }^{8}$

\section{Considerações finais}

Levando em conta a origem milenar da estratégia baseada no duplo poder, origem ligada à tradição dialética, seria razoável pensar que uma modificação no Estado burguês que o tornou mais complexo pudesse justificar o abandono de uma estratégia ligada a um método cuja tradição remonta há mais de 2.000 anos? Não teria Gramsci se precipitado ao propor uma nova estratégia que, segundo ele, deveria substituir a estratégia baseada no duplo poder? Para negar essa estratégia não seria necessário negar também o método dialético, ambos frutos de uma mesma origem?

No Brasil, a estratégia geral das direções hegemônicas da classe trabalhadora das últimas cinco décadas teve, em maior ou menor grau, a influência mais ou menos consciente do Gramsci dos Cadernos do Cárcere, frequentemente distorcida e vulgarizada, conduzindo a classe à conquista da hegemonia nos conselhos de saúde, nos conselhos de educação, conselhos de segurança pública, todos vinculados ao Estado burguês, além dos sindicatos, das associações de classe etc., na busca de elaborar e colocar em prática politicas públicas e reivindicações econômicas que garantissem a melhoria das condições de vida dos trabalhadores sob o capitalismo. A burguesia não teria, com isso, conseguido criar uma espécie de "cinturão protetor" composto por uma potente e milionária estrutura sindical e partidária que passou a dirigir a classe trabalhadora? Não são justamente essas estruturas que, há décadas, propõem pactos com a burguesia, como novas constituições burguesas, impeachment de presidentes etc., bloqueando os levantes de massa e impedindo que eles deem início a um processo de dualidade de poder? Em que medida essas organizações sindicais e partidárias não cumpriram e continuam cumprindo este nefasto papel? A perspectiva originária de Marx e Engels, seguida por Lênin e Trotsky, de construir as condições da revolução através do duplo poder permanece, assim, soterrada pela burguesia e seus representantes nas organizações proletárias, tornando a revolução socialista algo totalmente dissociado da luta cotidiana, algo para um possivel futuro distante, tornando-a uma expressão vazia, uma utopia.

A questão a ser debatida é se essa nova configuração dos Estados dos países avançados do Ocidente composta por organizações da sociedade civil cuja função frequente é a de amortecer a luta de classes, exige, de fato, uma nova estratégia revolucionária, ou, em sentido contrário, a estratégia milenar da construção de conselhos de trabalhadores continua atual.

\section{Referências}

ANWEILER, Oskar. Los soviets en Rusia (1905-1921) Madrid: Zero, 1975

ACHCAR, Gilbert. A revolução russa. In: LÖWY, Michael (org.). Revoluções. São Paulo: Boitempo, 2009, p. 71-81.

\footnotetext{
Na língua grega a expressão Alétheia significa "não esquecimento" ( $\mathrm{A}$ = negação; Léthe = esquecer), e ao mesmo tempo está ligada à noção de verdade. Ou seja, para os gregos, a verdade significa retirar a história do esquecimento, a verdade está ligada a um processo histórico, história que, para Marx, é indissociável da luta de classes (MARX; ENGELS, 2010, p. 40).

8 A respeito da criação do método dialético no diálogo Sofista, ver Benoit (2017, p. 271-331).
} 
BARSSOTI, Paulo. "Estamos aqui pela humanidade!" Viva a Comuna de Paris de 1871! Revista Brasil Revolucionário, [S. /], n. 29, 2001. Disponivel em: http:// www4.pucsp.br/neils/downloads/v8_paulo_basotti. pdf. Acesso em: 3 ago. 2020.

BENOIT, Hector. Sobre a critica (dialética) de O Capital. Revista Crítica

Marxista, São Paulo, n. 3, p. 14-44, 1996. Disponivel em: https://www.ifch.unicamp.br/criticamarxista/arquivos biblioteca/artigo16Art1.2.pdf. Acesso em: 4 jun. 2021;

BENOIT, Hector._Sobre o desenvolvimento (dialético) do programa. Revista Crítica Marxista, São Paulo, n. 4. p. 9-44, 1997. Disponivel em: https://www.ifch.unicamp. br/criticamarxista/arquivos_biblioteca/artigoz2Artigo1. pdf. Acesso em: 4 jun. 2021.

BENOIT, Hector. Platão e as temporalidades: a questão metodológica. São Paulo: Annablume, 2015.

BENOIT, Hector. Reflexões sobre o esquecimento do programa marxista. In: GALVÃO, Andréia; NETO, Benedito Moraes et al. (org.). Marxismo e socialismo no século 21. Campinas: UNICAMP/IFCH: Xamã, 2005. p. 87-98.

BENOIT, Hector. A odisseia de Platão: as aventuras e desventuras da dialética. São Paulo: Annablume, 2017.

BROUÉ, Pierre. O partido bolchevique. São Paulo: Instituto José Luis e Rosa Sundermann, [197-]. v. 1.

BROUÉ, Pierre. O partido bolchevique. São Paulo: Instituto José Luis e Rosa Sundermann, [197-]. v. 2.

DILLENBURG, Fernando Frota. Gramsci e o novo programa. 2011. Tese (Doutorado em Filosofia) - Universidade Estadual de Campinas, Campinas, 2011

GRAMSCI, Antonio. Cadernos do cárcere. 3. ed. Rio de Janeiro: Civilização Brasileira, 2004. v. 1.

GRAMSCI, Antonio. Cadernos do cárcere. 3. ed. Rio de Janeiro: Civilização Brasileira, 2004. v. 2.

GRAMSCl, Antonio. Cadernos do cárcere, 3. ed. Rio de Janeiro: Civilização Brasileira, 2004. v. 3

GRAMSCI, Antonio. Cadernos do cárcere. 3. ed. Rio de Janeiro: Civilização Brasileira, 2004. v. 4.

GRAMSCI, Antonio. Cadernos do cárcere. 3. ed. Rio de Janeiro: Civilização Brasileira, 2004. v. 5.

GRAMSCI, Antonio. Cadernos do cárcere. 3. ed. Rio de Janeiro: Civilização Brasileira, 2004. v. 6.

GRAMSCl, Antonio. Escritos políticos. Rio de Janeiro: Civilização Brasileira, 2004.

LENIN, Vladimir Ilitch. El "izquierdismo", enfermedad infantil del comunismo. México: Akal, 1978. (Obras completas, t. XXXIII).

GRAMSCI, Antonio. En memoria de la comuna. México: Akal, 1978. (Obras completas, t. XVII).

LUXEMBURGO, Rosa. Greve de massas, partido e sindicatos. Coimbra: Centelha, 1974.
MARX, Karl. O capital: critica da economia política. São Paulo: Abril Cultural, 1984.

MARX, Karl; ENGELS, Friedrich. Mensagem do Comitê Central à Liga dos Comunistas. São Paulo: Alfa-Ômega, [195-]. (Obras escolhidas).

MARX, Karl; ENGELS, Friedrich. Manifesto comunista. São Paulo: Boitempo, 2010

MIÉVILLE, China. Outubro: história da revolução russa. São Paulo: Boitempo, 2017.

PADIAL, Rafael de Almeida. Ascensão e queda do Programa de Transição. Parte 1. In: Transição Socialista. [S. /], 28 maio, 2015. Disponivel em: http://www.transicao.org/negacaodanegacao/producoes-teoricas/ ascensao-e-queda-do-programa-de-transicao-parte-1. Acesso em: 4 jun. 2021.

PLATÃo. Diálogos. São Paulo: Nova Cultural, 1991. (Os pensadores)

\section{PLATÃO. As leis. 2. ed. Bauru: EDIPRO, 2010.}

TESIS, manifiestos y resoluciones adoptados por los cuatro primeros congresos de la Internacional Comunista (1919-1923). Textos completos. 2017. Disponivel em: https://Www.marxists.org/espanol/comintern/ eis/4-Primeros3-Inter-2-edic.pdf.Acesso em: 4 jun. 2021.

TROTSKY, Leon. A história da revolução russa. 2. ed. Rio de Janeiro: Paz e Terra, 1977.

TROTSKY, Leon. O programa de transição: a agonia do capitalismo e as tarefas da Quarta Internacional. São Paulo: Týkhe, 2009.

ZINOVIEV, Grigori. Quando e sob quais condições podem ser criados os sovietes operários? In: PINHEIRO, Milton; MARTORANO, Luciano Cavini (org.). Teoria e prática dos conselhos operários. São Paulo: Expressão Popular, 2013. p. 85-88.

\section{Fernando Frota Dillenburg}

Doutor em Filosofia pela Universidade Estadual de Campinas (UNICAMP), em Campinas, SP, Brasil; professor do Departamento de Economia e Relações Internacionais da Universidade Federal do Rio Grande do Sul (UFRGS), em Porto Alegre, RS, Brasil.

\section{Endereço para correspondência}

Fernando Frota Dillenburg

Universidade Federal do Rio Grande do Sul

Av. João Pessoa, 52, sala 28-D

Centro Histórico, 90046-901

Porto Alegre, RS, Brasil

Os textos deste artigo foram revisados pela Poá Comunicação e submetidos para validação do autor antes da publicação. 